\title{
KESESUAIAN LAHAN UNTUK BUDIDAYA UDANG WNDU (Penaeus monodon) DI TAMBAK KABUPATEN BREBES,JAWA TENGAH
}

\author{
Rezki Antoni Suhaimi, Hasnawi, dan Erna Ratnawati
}

Balai Penelitian dan Pengembangan Budidaya Air Payau

Jl. Makmur Dg. Sitakka No. 129, Maros 90512, Sulawesi Selatan

E-mail: rezki.antoni.s@gmail.com

(Naskah diterima: 6 Maret 2013; Disetujui publikasi: 3 September 2013)

\begin{abstract}
ABSTRAK
Wilayah Kabupaten Brebes terletak di bagian paling Barat dari Provinsi Jawa Tengah dengan batas sebelah Utara Laut Jawa, sebelah Timur berbatasan dengan Kabupaten Tegal dan Kota Tegal, sebelah Selatan berbatasan dengan Kabupaten Banyumas dan sebelah Barat dengan Wilayah Cirebon. Evaluasi kesesuaian Iahan sangat penting dilakukan karena lahan memiliki sifat fisik, sosial, ekonomi, dan geografi yang bervariasi. Penelitian ini dilakukan dengan tujuan untuk mengetahui karakteristik lahan sebagai upaya untuk menentukan kesesuaian dan pengelolaan lahan untuk budidaya udang windu di tambak Kabupaten Brebes Provinsi Jawa Tengah. Faktor yang dipertimbangkan dalam mengetahui karakteristik Iahan adalah: topografi dan elevasi, tanah, hidrologi, dan iklim. Analisis spasial dalam sistem informasi geografis (SIG) digunakan untuk menentukan kesesuaian lahan budidaya udang. Hasil evaluasi kesesuaian lahan yang dilakukan di dalam penelitian ini merupakan kesesuaian aktual atau kesesuaian lahan pada saat dilaksanakan penelitian. Hasil penelitian menunjukkan bahwa dari hasil analisis kesesuaian lahan tambak di Kabupaten Brebes, didapat nilai kesesuaian untuk budidaya udang windu, sangat sesuai (S1) seluas 134,7 ha; cukup sesuai (S2) seluas $4.290,05$ ha; sesuai bersyarat (S3) seluas $6.414,73$ ha; dan tidak sesuai (N) seluas 469,34 ha.
\end{abstract}

KATA KUNCI: kesesuaian Iahan, tambak, udang windu, Kabupaten Brebes

ABSTRACT: Land suitability aquaculture for tiger prawn (Penaeus monodon) brackishwater pond in Brebes Regency, Central Java. By: Rezki Antoni Suhaimi, Hasnawi, and Erna Ratnawati

Brebes district is located in the most western part of Central Java with the Java Sea North boundary, adjacent to the East and Tegal Regency, the South by the Banyumas Regency, and West to the region of Cirebon. Land suitability evaluation is very important because the land has varied of the physical, social, economic, and geography. This research was conducted to determine the characteristics of land in an effort to determine the suitability of land for cultivation and management of tiger shrimp ponds Brebes in Central Java Province. Know the factors considered in land characteristics are: topography and elevation, soil, hydrology, and climate. Spatial Analysis in Geographic Information Systems (GIS) are used for determining suitability for shrimp farming. Results of land suitability evaluation conducted in this study is the actual suitability or appropriateness of the land at the time of the research carried out. The result showed that the analysis of land suitability farms in Bradford County, obtained value suitability for tiger shrimp, very suitable (S1) area of 134.7 
ha; quite suitable (S2) area of 4,290.05 ha; corresponding conditional (S3) area of $6,414.73 \mathrm{ha}$; and not suitable (N) covering an area of 469.34 ha.

\section{KEYWORDS: land suitability, brackishwater pond, tiger prawn, Brebes Regency}

\section{PENDAHULUAN}

Wilayah Kabupaten Brebes terletak di bagian paling Barat dari Provinsi Jawa Tengah dengan batas sebelah Utara Laut Jawa, sebelah Timur dengan Kabupaten Tegal dan Kota Tegal, sebelah Selatan dengan Kabupaten Banyumas dan sebelah Barat dengan Wilayah Cirebon. Secara topografis wilayah Kabupaten Brebes memiliki potensi daerah pantai yang meliputi Kecamatan Brebes, Kecamatan Wanasari, Kecamatan Bulakamba, Kecamatan Tanjung, dan Kecamatan Losari dengan luas lahan pertambakan 12.748 ha, dan jumlah pembudidaya tambak sebanyak 4.027 orang (Anonim, 2011).

Komoditas yang dibudidayakan di tambak Kabupaten Brebes pada umumnya adalah ikan bandeng dan udang. Pada tahun 1990-an, usaha tambak bandeng dan udang adalah primadona bagi masyarakat pesisir Kabupaten Brebes. Namun, penggunaan racun yang berlebihan telah membuat turunnya kualitas tambak di Kabupaten Brebes. Sehingga untuk selanjutnya budidaya tambak perlu memperhatikan daya dukung lahan. Pengembangan tambak yang melampaui daya dukung lingkungan, tentunya akan membuat potensi tambak tidak akan menghasilkan output yang optimal, dan jika dibiarkan akan mempengaruhi kondisi air dan tanah pertambakan.

Semua jenis komoditas termasuk komoditas perikanan budidaya yang berbasis lahan untuk dapat tumbuh atau hidup dan berproduksi memerlukan persyaratan- persyaratan tertentu, yang dapat berbeda satu sama lain (Mustafa et al., 2011). Dalam kaitannya dengan sumberdaya alam, dikenal istilah lahan yang merupakan suatu lingkungan fisik yang terdiri atas tanah, topografi, hidrologi, vegetasi, dan iklim di mana pada batas- batas tertentu mempengaruhi kemampuan penggunaan lahan (FAO, 1976).

Evaluasi kesesuaian lahan sangat penting dilakukan karena lahan memiliki sifat fisik, sosial, ekonomi, dan geografi yang bervariasi atau lahan diciptakan tidak sama (Mustafa et al., 2008). Evaluasi kesesuaian lahan dapat memprediksi keragaan Iahan dalam hal keuntungan yang diharapkan dari penggunaan lahan dan kendala penggunaan lahan yang produktif, serta degradasi lingkungan yang diperkirakan akan terjadi karena penggunaan Iahan. Kesesuaian Iahan merupakan suatu kunci sukses dalam kegiatan akuakultur yang mempengaruhi kesuksesan dan keberlanjutannya, serta dapat memecahkan konflik antara berbagai kegiatan dan membuat penggunaan lahan lebih rasional (Bojo' rquez- Tapia et al., 2001; Hossain \& Das, 2010; RodriguezGallego et al., 2012).

Sistem informasi geografis (SIG) merupakan suatu sistem informasi yang mampu mengintegrasikan berbagai data, baik data spasial maupun nonspasial, melalui berbagai pengolahan. Teknologi SIG dibutuhkan untuk memperbaiki kesesuaian pengolahan wilayah dan sekaligus merupakan bahan masukan bagi pengambilan keputusan dalam rangka mendukung pengembangan wilayah (Puntodewo, 2003).

Penelitian ini dilakukan bertujuan untuk menentukan kesesuaian lahan untuk budidaya udang windu di tambak Kabupaten Brebes Provinsi Jawa Tengah, sehingga dapat dijadikan pertimbangan dalam pengelolaan budidaya berkelanjutan.

\section{BAHAN DAN METODE}

Penelitian ini dilaksanakan pada bulan Juli 2012. Pengambilan contoh dilakukan di kecamatan yang terletak di pesisir Kabupaten Brebes Provinsi Jawa Tengah (Gambar 1).

Sumber data yang digunakan adalah Citra ALOS (Advanced Land Observing Satellite) AVNIR- 2 (The Advanced Visible and Near Infrared Radiometer type 2) akuisisi tahun 2010, serta peta administratif dari BAKOSURTANAL (Badan Koordinasi Survai dan Pemetaan Nasional).

Data primer yang dikumpulkan meliputi data biofisik yaitu: pasang surut, topografi dan hidrologi, kondisi tanah, dan kualitas air. Pengukuran pasang surut dilakukan di salah satu titik pengamatan di lokasi penelitian 
dengan menggunakan palem atau rambu pengamat pasang surut dengan interval satu jam. Hasil pengukuran pasang surut dikoreksi dengan data pasang surut dari Dinas HidroOseanografi (2012) pada stasiun terdekat.

Penentuan titik- titik pengambilan contoh tanah didasarkan pada peta satuan unit. Pengambilan contoh tanah dilakukan pada beberapa titik pada kedalaman 0-0,2 $\mathrm{m}$ dan 0,5- 0,7 $\mathrm{m}$ dari permukaan. Peubah kondisi tanah yang diukur dengan $\mathrm{pH}$ meter langsung di lapangan adalah $\mathrm{pH}_{\mathrm{F}}$ dan $\mathrm{pH}_{\mathrm{FOx}}(\mathrm{pH}$ tanah yang diukur di lapangan setelah dioksidasi dengan hidrogen peroksida $\left(\mathrm{H}_{2} \mathrm{O}_{2}\right) 30 \%$.

Peubah tanah dianalisis di Laboratorium Tanah Balai Penelitian dan Pengembangan Budidaya Air Payau (BPPBAP) Maros meliputi bahan organik dengan metode Walkley \& Black (Sulaeman et al., 2005), dan tekstur dengan metode hidrometer (Agus et al., 2006).

Pengukuran dan pengambilan contoh air dilakukan di sungai, laut, saluran, dan tambak. Pengukuran dan pengambilan contoh air di tambak mengikuti titik pengambilan contoh tanah. Peubah kualitas air yang diukur langsung di lapangan adalah suhu, salinitas, oksigen terlarut, dan $\mathrm{pH}$ dengan menggunakan Hydrolab ${ }^{\circledR}$ Minisonde. Contoh air untuk analisis di laboratorium diambil dengan menggunakan Kmerer Water Sampler dan dipreservasi mengikuti petunjuk APHA (2005). Peubah kualitas air yang dianalisis di Labo- ratorium Air BPPBAP di Maros meliputi: $\mathrm{NH}_{4}$ $\mathrm{NO}_{3}, \mathrm{NO}_{2}, \mathrm{SO}_{4}, \mathrm{Fe}$, dan padatan tersuspensi total mengikuti petunjuk Menon (1973), Parson et al. (1989), dan APHA (2005). Seluruh titik- titik pengambilan contoh ditentukan titik koordinatnya dengan menggunakan global positioning system (GPS).

Setelah data terkumpul maka dilakukan analisis spasial, untuk keperluan analisis spasial dilakukan penyusunan basis data (spasial dan atribut). Penyusunan data spasial melalui proses digitasi, editing, tranformasi koordinat, buffering, overlay dan map composition.

Data atribut disusun untuk memberikan informasi mengenai kenampakan spasial yang ada. Data atribut akan ditampilkan pada kenampakan spasial dalam bentuk area atau polygon. Data yang disusun meliputi data atribut table yang merupakan info file (text file) yang memperlihatkan hubungan antar item yang ada (Prahasta, 2001).

Analisis spasial dilakukan untuk menentukan wilayah yang potensial sebagai pengembangan lahan untuk budidaya tambak berdasarkan kriteria yang telah ditentukan. Pada proses analisis menggunakan program ArcGIS 9.3 dengan cara memasukkan setiap peubah data untuk menghasilkan peta tematik bagi setiap peubah data dan selanjutnya dilakukan proses tumpang tindih. Kriteria yang digunakan dalam penentuan kesesuaian lahan untuk

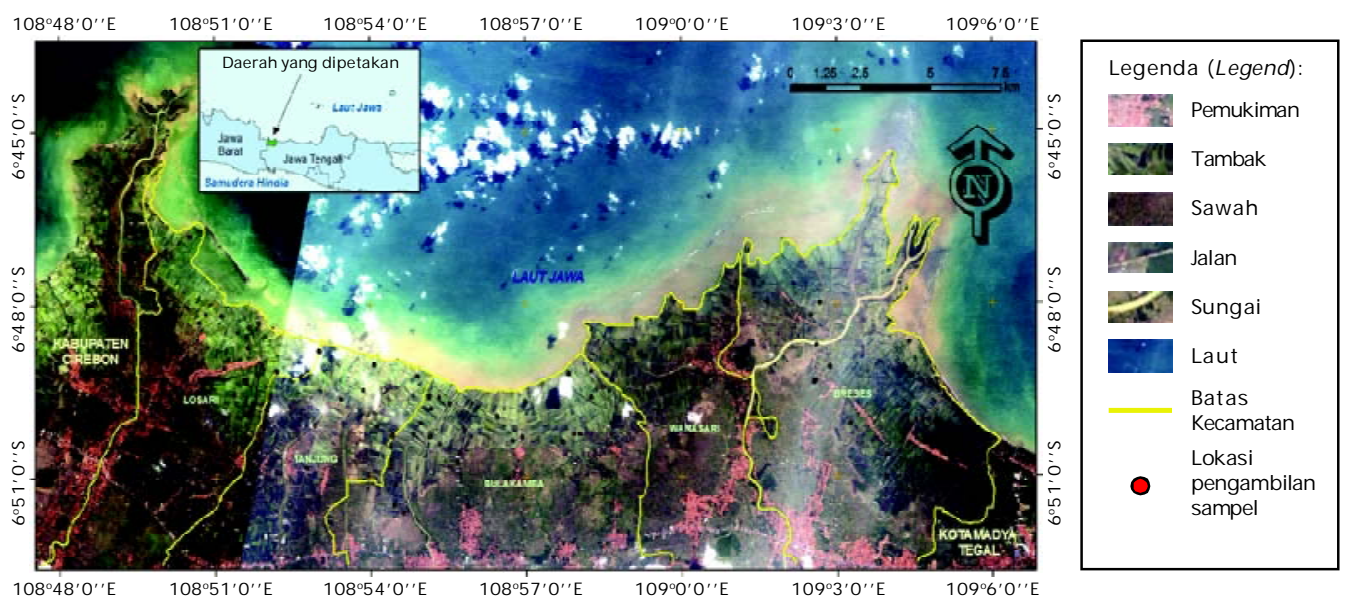

Gambar 1. Peta titik- titik pengambilan contoh di kawasan pertambakan Kabupaten Brebes Provinsi Jawa Tengah

Figure 1. Study area and distribution of sampling points at brackishwater pond region in Brebes Regency Central Java Province 
budidaya tambak mengacu pada kriteria yang ada (Tabel 1).

\section{HASIL DAN BAHASAN}

\section{Gambaran Umum Lokasi}

Kabupaten Brebes memiliki areal tambak terluas di Jawa Tengah yaitu 12.748 ha, dengan jumlah pembudidaya tambak sebanyak 4.027 orang (Anonim, 2011). Komoditas yang dibudidayakan pada umumnya adalah ikan bandeng dan udang. Wilayah tambak di Kabupaten Brebes sepanjang Pantura meliputi lima kecamatan, yaitu Kecamatan Brebes, Wanasari, Bulakamba, Tanjung, dan Losari
(Gambar 1). Jarak terjauh rentang wilayah Kabupaten Brebes arah Utara- Selatan sekitar $58 \mathrm{~km}$ dan jarak terjauh rentang Timur- Barat sekitar $50 \mathrm{~km}$.

\section{Karakteristik Lahan}

\section{Topografi}

Kemiringan lahan sangat mempengaruhi pengelolaan lahan tambak. Lahan yang curam selain memerlukan banyak biaya untuk penggalian dan perataan tanah untuk pembukaan lahan baru, juga berdampak pada hilangnya lapisan tanah permukaan yang subur pada saat pembuangan air. Oleh karena itu, sangat pen-

Tabel 1. Kriteria kesesuaian lahan untuk budidaya udang windu (Penaeus monodon) di tambak

Table 1. Land suitability criteria for tiger prawn (Penaeus monodon) culture in brackishwater ponds

\begin{tabular}{|c|c|c|c|c|}
\hline \multirow{2}{*}{$\begin{array}{l}\text { Faktor/ Peubah } \\
\text { Factor/Variables }\end{array}$} & \multicolumn{4}{|c|}{ Kelas (Class) } \\
\hline & S1 & $\mathbf{S 2}$ & S3 & $\mathbf{N}$ \\
\hline \multicolumn{5}{|c|}{ Topografi \& hidrologi (Topography \& hydrology): } \\
\hline Kemiringan (Slope) $(\%$ & $<1.0$ & $1.0-2.0$ & $2.0-3.0$ & $>3.0$ \\
\hline Pasang surut (Tidal range ) (m) & $1.5-2.5$ & $\begin{array}{l}1.0-1.5 \\
2.5-3.0\end{array}$ & $\begin{array}{l}0.5-1.0 \\
3.0-3.5\end{array}$ & $\begin{array}{l}<0.5 \\
>3.5\end{array}$ \\
\hline \multicolumn{5}{|l|}{ Kondisi tanah (Soil conditions): } \\
\hline $\begin{array}{l}\text { Ketebalan tanah sampai menc apai batuan } \\
\text { Thickness of the soil to reaches rock }(\mathrm{m})\end{array}$ & $>2.0$ & $1.5-2.0$ & $1.0-1.5$ & $<1.0$ \\
\hline Kedalaman pirit (Depth of pyrite) (m) & $>2.0$ & $1.0-2.0$ & $0.5-1.0$ & $<0.5$ \\
\hline Liat (Clay) $)(\%$ & $10-20$ & $20-30$ & $30-60$ & $<10 ;>60$ \\
\hline $\mathrm{pH}_{\mathrm{F}}-\mathrm{pH}_{\mathrm{FOx}}$ & $<0.5$ & $0.5-1.5$ & $1.5-4.0$ & $>4.0$ \\
\hline Karbon organik (Organic carbon ) $(\%$ & $1.5-2.5$ & $0.5-1.5$ & $<0.5 ; 2.5-8.0$ & $>8.0$ \\
\hline \multicolumn{5}{|l|}{ Kualitas air (Water quality): } \\
\hline Kecerahan (Transparency ) (m) & $0.30-0.40$ & $\begin{array}{l}0.25-0.30 \\
0.40-0.50\end{array}$ & $\begin{array}{l}0.20-0.25 \\
0.50-0.60\end{array}$ & $\begin{array}{l}<0.20 \\
>0.60\end{array}$ \\
\hline Suhu (Temperature) $\left({ }^{\circ} \mathrm{C}\right)$ & $28-30$ & $20-28 ; 30-35$ & $12-20 ; 35-40$ & $<12 ;>40$ \\
\hline Salinitas (Salinity ) (ppt) & $15-25$ & $10-15 ; 25-32$ & $5-10 ; 32-40$ & $<5 ;>40$ \\
\hline $\mathrm{pH}_{\mathrm{F}}-\mathrm{pH}_{\mathrm{FOX}}$ & $7.5-8.5$ & $\begin{array}{l}6.0-7.5 \\
8.5-9.5\end{array}$ & $\begin{array}{l}4.0-6.0 \\
9.5-11.0\end{array}$ & $\begin{array}{l}<4.0 \\
>11.0\end{array}$ \\
\hline Amonia (Ammonia ) & $<0.1$ & $0.1-0.2$ & $0.2-0.3$ & $>0.3$ \\
\hline \multicolumn{5}{|l|}{ Iklim (Climate): } \\
\hline $\begin{array}{l}\text { Curah hujan tahunan (mm/tahun) } \\
\text { Annual rainfall (mm/years) }\end{array}$ & $2,500-3,000$ & $2,000-2,500$ & $\begin{array}{c}3,000-3,500 \\
1,000-2,000\end{array}$ & $\begin{array}{l}>3,500 \\
<1,000\end{array}$ \\
\hline Bulan kering (Dry month ) $(<60 \mathrm{~mm})$ & $1-2$ & $2-3$ & 3-5 & $<1 ;>5$ \\
\hline
\end{tabular}

Sumber (Source): Mustafa et al. (2007) 
ting untuk memilih lahan dengan ciri relief lahan yang datar atau dengan kemiringan berkisar 0\% 1\%

Pada umumnya di daerah penelitian ini memiliki ciri relief datar yang berkisar $0 \% 1 \%$ dengan demikian lahan tersebut layak untuk dijadikan lahan tambak karena memadainya pasokan air laut dengan energi pasang dan pengaliran air tawar. Pasang surut di kawasan pesisir Kabupaten Brebes tergolong sangat rendah yaitu kurang dari 1,0 m (Gambar 2) dan kurang mendukung untuk usaha budidaya tambak.

\section{Kondisi Tanah}

Secara umum, tanah tambak di Kabupaten Brebes tergolong tanah aluvial non-sulfat masam yang dicirikan dengan nilai $\mathrm{pH}_{\mathrm{F}}-\mathrm{pH}_{\mathrm{FOx}}$ yang relatif rendah, yaitu 0,9723 (Tabel 2).
Tekstur tanah mempunyai peranan penting dalam menentukan lokasi pertambakan, karena berkaitan erat dengan kualitas tanah. Tanah tidak hanya berfungsi sebagai media tetapi juga berfungsi sebagai penyedia unsur hara bagi organisme budidaya. Dengan menganalisis perbandingan antara fraksi-fraksi tanah maka dapat diketahui kelas tekstur tanah pada suatu lahan untuk pertambakan. Mangunsukardjo (1997) menyatakan bahwa, tekstur tanah adalah salah satu faktor penting yang mempengaruhi kapasitas tanah untuk menahan air. Porositas rendah menunjukkan tanah dapat menahan peresapan air dan menjadi penghalang intrusi air laut secara berlebihan, hal ini merupakan salah satu kriteria pentingnya memilih kesesuaian Iahan berdasarkan tekstur. Sebaran frakis liat pada tambak Kabupaten Brebes dapat dilihat pada Gambar 3.

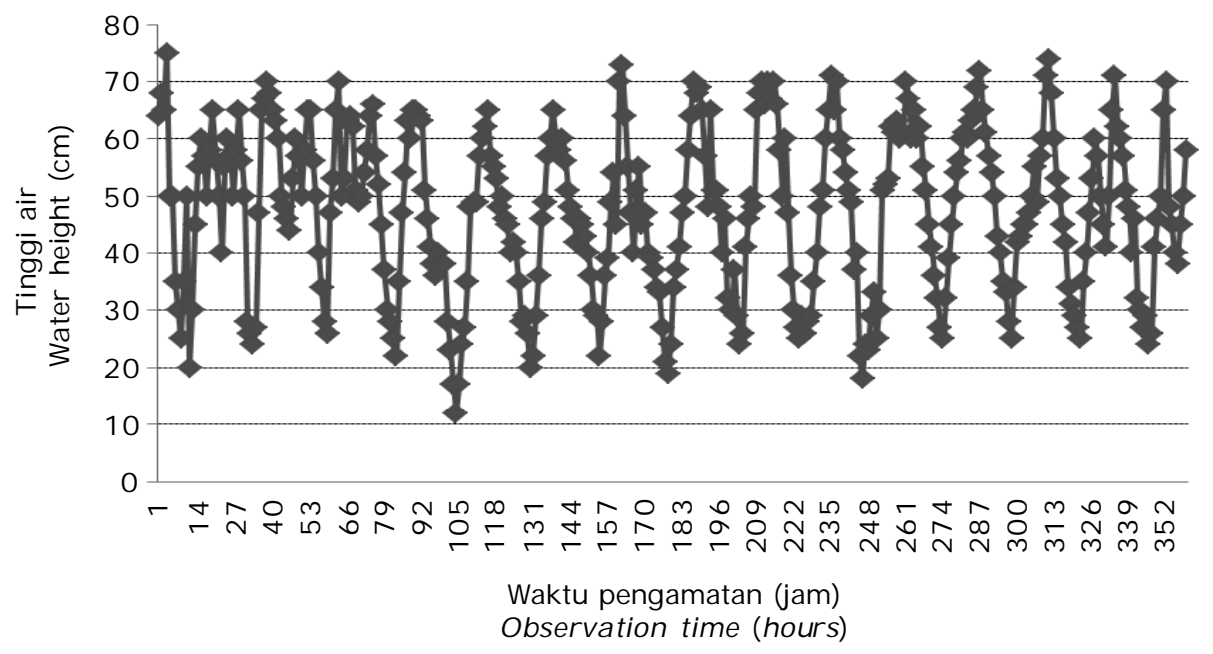

Gambar 2. Pasang surut di kawasan pesisir Kabupaten Brebes Provinsi Jawa Tengah

Figure 2. Tidal conditions in coastal area of Brebes Regency Central Java Province

Tabel 2. Statistik deskriptif kualitas tanah di kawasan pertambakan Kabupaten Brebes Provinsi Jawa Tengah

Table2. Descriptive statistics of soil quality in brackishwater ponds of Brebes Regency Central Java Province

\begin{tabular}{lcccc}
\hline $\begin{array}{c}\text { Peubah } \\
\text { Variables }\end{array}$ & Minimum & $\begin{array}{c}\text { Maksimum } \\
\text { Maximum }\end{array}$ & $\begin{array}{c}\text { Rataan } \\
\text { Average }\end{array}$ & $\begin{array}{c}\text { Standar deviasi } \\
\text { Standard deviation }\end{array}$ \\
\hline $\mathrm{pH}_{\mathrm{F}}-\mathrm{pH}_{\mathrm{FOx}}$ & 0.001 & 5.500 & 0.972 & 1.004 \\
Karbon organik (Organic carbon ) $(\%)$ & 0.23 & 2.33 & 1.12 & 0.44 \\
Fraksi liat (Clay fraction) $(\%)$ & 0.01 & 68.00 & 35.58 & 19.61 \\
\hline
\end{tabular}




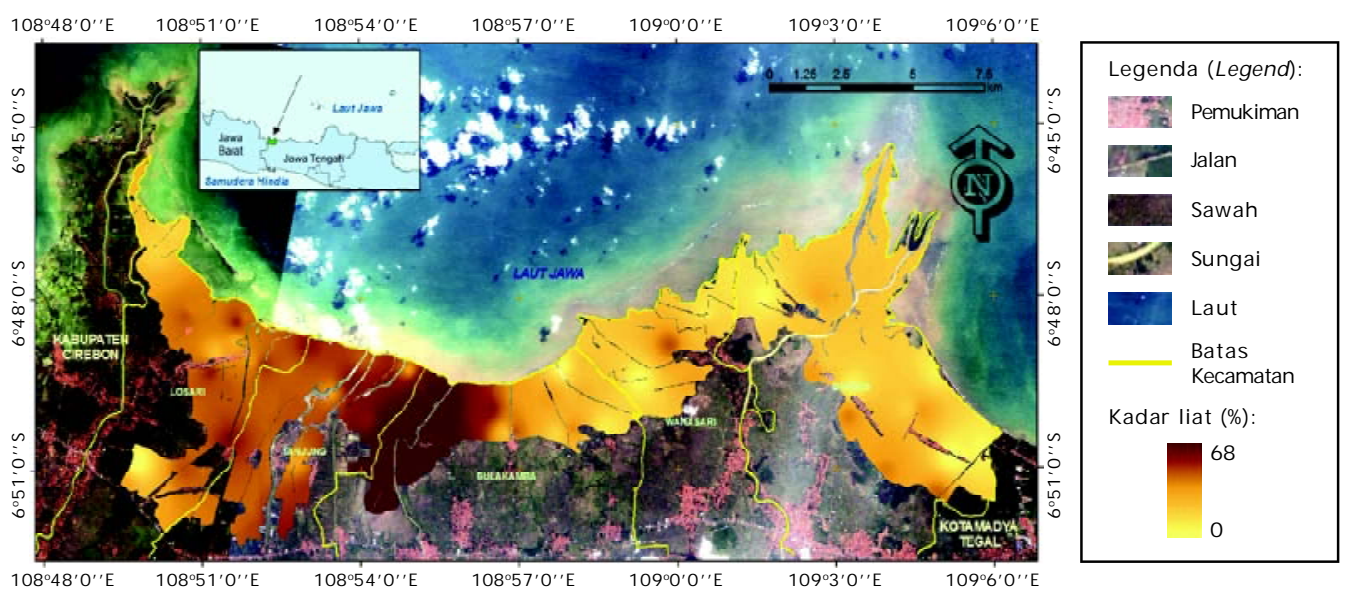

Gambar 3. Peta fraksi liat tanah di kawasan pertambakan Kabupaten Brebes Provinsi Jawa Tengah

Figure 3. Clay fraction map of soil in brackishwater ponds of Brebes Regency Central Java Province

$\mathrm{pH}$ tanah merupakan tingkat kemasaman atau kebasaan tanah, dalam hal ini merupakan konsentrasi ion hidrogen $\left(\mathrm{H}^{+}\right)$efektif atau merupakan aktivitas ion hidrogen. Tanah yang bersifat asam akan menunjukkan nilai $\mathrm{pH}<7$ dan bersifat basa $\mathrm{pH}>7$, sedangkan yang bersifat netral mempunyai nilai $\mathrm{pH}=7$. Reaksi tanah bagi tambak harus netral atau sedikit lebih tinggi dan tidak berpotensi masam.

Menurut Tarunamulia et al. (2003), Iahan pantai yang sangat baik hingga cukup baik untuk dikembangkan menjadi tambak sebaiknya memiliki selisih nilai $\mathrm{pH}_{\mathrm{F}}$ dan $\mathrm{pH}_{\mathrm{Fox}}$ kurang dari 3. Hasil interpolasi sebaran dari nilai $\mathrm{pH}_{\mathrm{F}}-\mathrm{pH}_{\mathrm{Fox}}$ dapat dilihat pada Gambar 4.

Bahan organik dalam tanah adalah sumber utama nitrogen dan fosfor untuk pertumbuhan makanan alami. Makin tinggi kandungan bahan organik makin besar kandungan nitrogennya. Namun, kandungan bahan organik yang tinggi dapat menurunkan kualitas lingkungan untuk budidaya di tambak (Mustafa et al., 2008). Sebaran karbon organik pada tanah tambak Kabupaten Brebes dapat dilihat pada Gambar 5.

\section{Kualitas Air}

Kondisi kualitas perairan tambak dipengaruhi oleh sumber air (laut dan sungai). Jarak dari sumber air tidak hanya berpengaruh terhadap kuantitas air tetapi juga kualitas air. Kualitas air di kawasan pertambakan Kabupaten Brebes disajikan pada Tabel 3.
Pengaruh jarak dari sumber air terhadap kondisi air tambak, juga ditentukan oleh kemiringan lereng, elevasi, serta perbedaan pasang surut (Mustafa et al., 2008). Sebagai negara tropis, iklim juga turut mempengaruhi kondisi kualitas air pada lokasi budidaya. Akan tetapi perbedaan kondisi kualitas perairan tidak akan terlalu ekstrem walau terjadi pergantian musim.

\section{Suhu}

Suhu air yang layak untuk budidaya udang windu berkisar antara $26^{\circ} \mathrm{C}$ dan $32^{\circ} \mathrm{C}$ dan optimumnya antara $29^{\circ} \mathrm{C}$ dan $30^{\circ} \mathrm{C}$ (Rachmansyah et al., 2010). Lebih lanjut dikatakan bahwa pada suhu $26^{\circ} \mathrm{C}-30^{\circ} \mathrm{C}$ pertumbuhan udang windu relatif cepat dengan sintasan yang relatif tinggi. Dikatakan bahwa udang windu dapat hidup pada suhu $14^{\circ} \mathrm{C}-40^{\circ} \mathrm{C}$, tetapi kisaran optimum untuk pertumbuhannya adalah $26^{\circ} \mathrm{C}$ $32^{\circ} \mathrm{C}$. Di dalam tambak suhu dapat memengaruhi aktivitas fotosintesis alga serta kelarutan gas- gas yang berada di dalamnya.

Suhu air sangat berpengaruh terhadap sifat fisik, kimia, dan biologi tambak, yang akibatnya mempengaruhi fisiologis kehidupan organisme budidaya, secara umum laju pertumbuhan udang akan meningkat sejalan dengan kenaikan suhu sampai pada batasbatas tertentu (Irianti, 2004). Secara umum kondisi suhu pada air tambak Kabupaten Brebes, masih dalam kondisi yang bisa digunakan untuk budidaya udang windu (Tabel 3, Gambar 6). 
Tabel 3. Kisaran parameter kualitas air di kawasan pertambakan Kabupaten Brebes Provinsi Jawa Tengah

Table3. Range of parameter water quality in brackishwater pond region of Brebes Regency Central Java Province

\begin{tabular}{lcccc}
\hline \multicolumn{1}{c}{$\begin{array}{c}\text { Peubah } \\
\text { Variables }\end{array}$} & Minimum & $\begin{array}{c}\text { Maksimum } \\
\text { Maximum }\end{array}$ & $\begin{array}{c}\text { Rataan } \\
\text { Average }\end{array}$ & $\begin{array}{c}\text { Standar deviasi } \\
\text { Standard deviation }\end{array}$ \\
\hline Suhu (Temperature) $\left({ }^{\circ} \mathrm{C}\right)$ & 24.31 & 36.25 & 30.53 & 2.37 \\
Salinitas (Salinity) $(\mathrm{ppt})$ & 14.81 & 70.74 & 39.78 & 12.48 \\
Oksigen terlarut & 1.53 & 7.62 & 3.90 & 1.23 \\
$\mathrm{Dissolved} \mathrm{oxygen} \mathrm{(mg/} \mathrm{L)}$ & & & & 6.46 \\
$\mathrm{pH}$ & 6.24 & 6.90 & 8.85 & 0.7112 \\
$\mathrm{NO}_{3}(\mathrm{mg} / \mathrm{L})$ & 0.0177 & 45.832 & 0.3674 & 0.3072 \\
$\mathrm{NO}_{2}(\mathrm{mg} / \mathrm{L})$ & 0.0008 & 28.134 & 0.0594 & 0.2442 \\
$\mathrm{NH}_{3}(\mathrm{mg} / \mathrm{L})$ & 0.0210 & 16.814 & 0.2457 & 0.2915 \\
$\mathrm{PO}_{4}(\mathrm{mg} / \mathrm{L})$ & 0.0001 & 18.862 & 0.1678 & \\
\hline
\end{tabular}

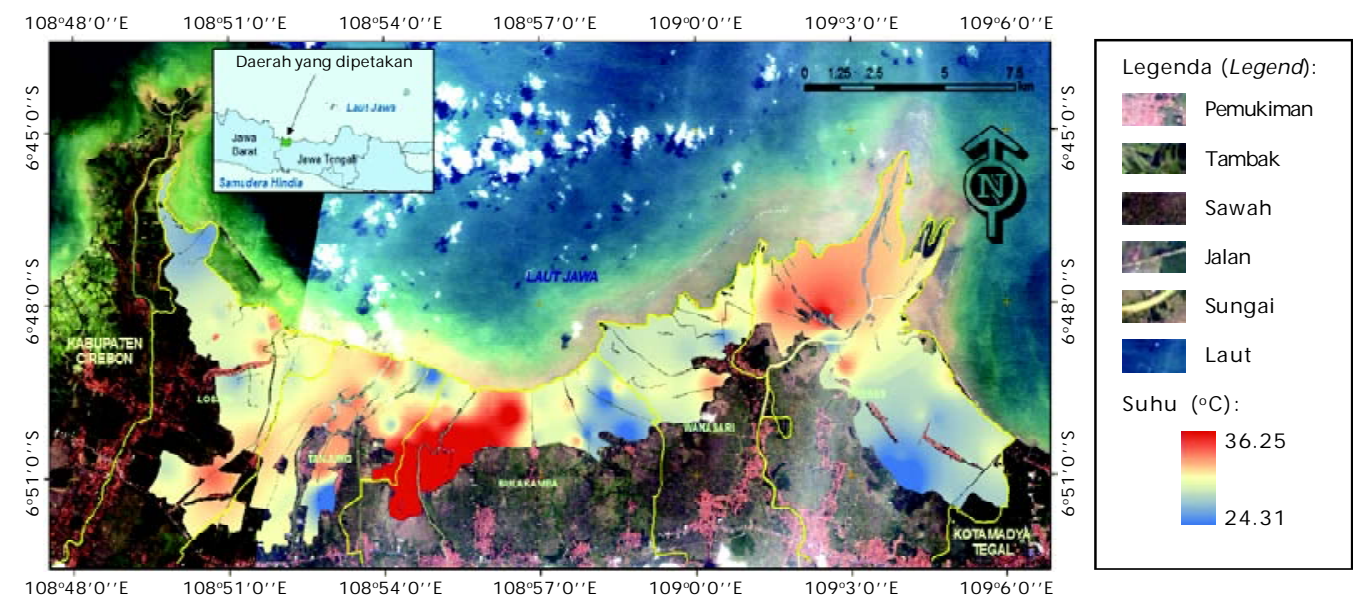

Gambar 6. Peta distribusi spasial suhu air tambak Kabupaten Brebes Provinsi Jawa Tengah

Figure 6. Spatial distribution map of water temperature in brackishwater pond of Brebes Regency, Central Java Province

kering, sehingga penguapan yang terjadi sangat besar dan tidak sebanding dengan input air yang masuk ke tambak. Artinya, sirkulasi air tambak sangat dibutuhkan untuk menjaga nilai salinitas tambak tetap pada kondisi yang optimal untuk budidaya.

\section{Derajat Keasaman (pH)}

Batas toleransi organisme akuatik terhadap $\mathrm{pH}$ bervariasi dan dipengaruhi oleh banyak faktor, antara lain suhu, oksigen terlarut, alkalinitas, serta jenis dan stadium organisme.
Kisaran $\mathrm{pH}$ yang baik untuk udang windu adalah 7,5-8,5 dengan optimum 8,0-8,5 (Mustafa et al., 2008). Pengukuran in situ terhadap nilai pH air tambak Kabupaten Brebes menunjukkan nilai yang netral dan memung-kinkan untuk budidaya tambak (Tabel 3, Gambar 8).

\section{Amonia $\left(\mathrm{NH}_{3}\right)$}

Amonia dapat berada dalam bentuk molekul $\left(\mathrm{NH}_{3}\right)$ atau bentuk ion $\mathrm{NH}_{4}$, di mana $\mathrm{NH}_{3}$ lebih beracun daripada $\mathrm{NH}_{4}$ (Poernomo, 1988). $\mathrm{NH}_{3}$ dapat menembus bagian membran sel 


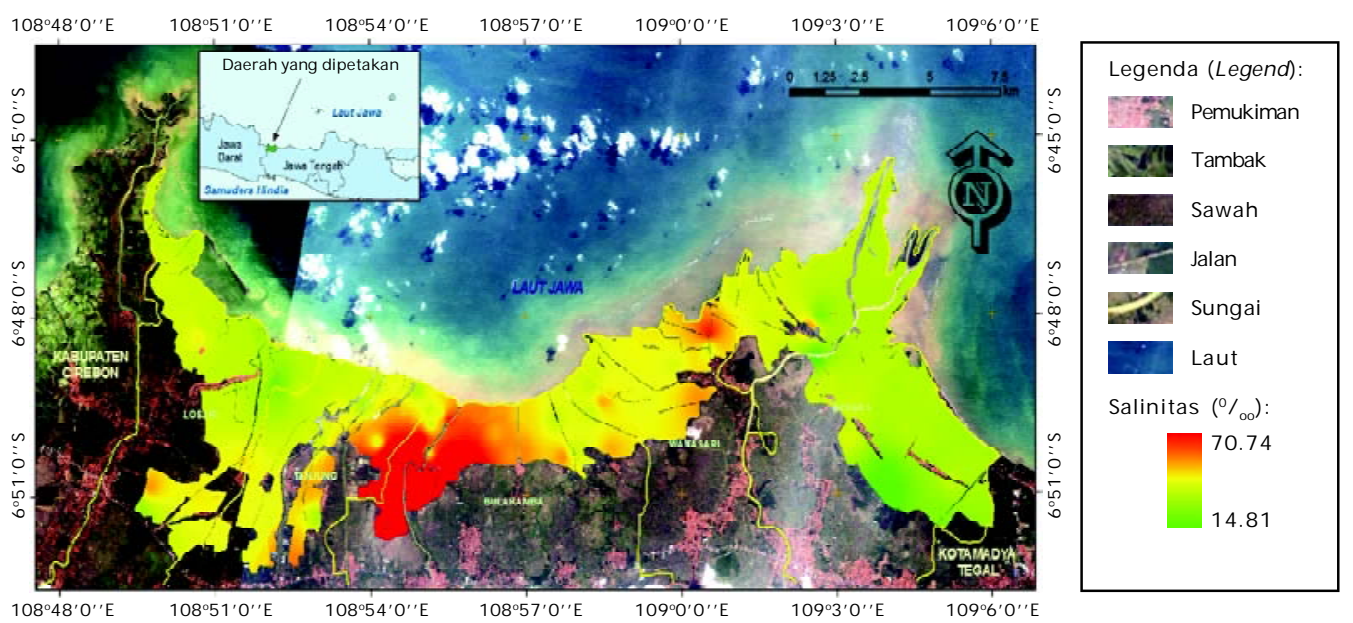

Gambar 7. Peta distribusi spasial salinitas air tambak Kabupaten Brebes Provinsi Jawa Tengah

Figure 7. Spatial distribution map of water salinity pond of Brebes Regency Central Java Province

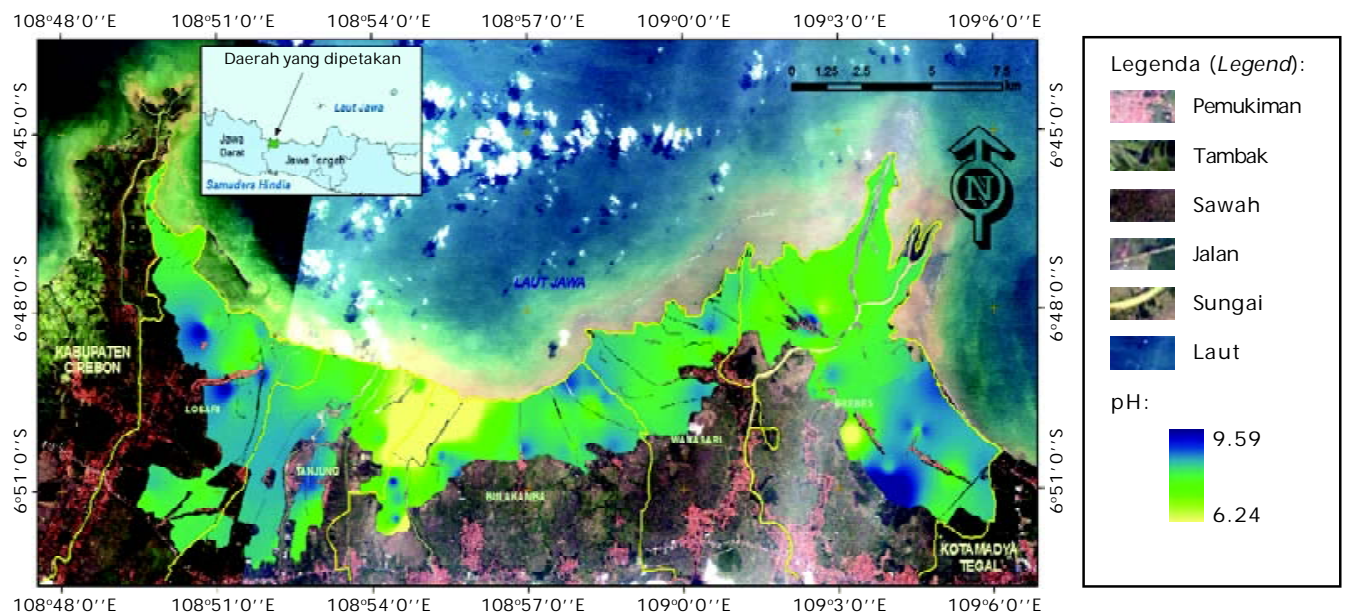

Gambar 8. Peta distribusi spasial pH air tambak Kabupaten Brebes Provinsi Jawa Tengah

Figure 8. Spatial distribution map of water $\mathrm{pH}$ in brackishwater ponds of Brebes Regency Central Java Province

lebih cepat daripada $\mathrm{NH}_{4}$. Kandungan $\mathrm{NH}_{3}$ 0,05- $0,20 \mathrm{mg} / \mathrm{L}$ sudah menghambat pertumbuhan organisme akuatik pada umumnya. Kandungan $\mathrm{NH}_{3}$ air tambak di Kabupaten Brebes tidak terdeteksi berkisar sampai 1,6814 $\mathrm{mg} / \mathrm{L}$ dengan rata- rata $0,2457 \mathrm{mg} / \mathrm{L}$ (Tabel 3, Gambar 9). Chanratchakool et al. (1995) menyatakan bahwa kandungan amonia yang diperkenankan untuk budidaya udang windu adalah kurang dari $0,1 \mathrm{mg} / \mathrm{L}$.

\section{Curah Hujan}

Kondisi rata- rata cuaca pada periode yang panjang dikenal dengan iklim. Unsur iklim yang penting untuk budidaya tambak adalah curah hujan. Curah hujan antara 2.000-3.000 mm/ tahun dengan bulan kering 2- 3 bulan cukup baik digunakan untuk tambak (Mustafa et al., 2011) (Gambar 10).

Persiapan tambak adalah salah satu kegiatan yang harus dilakukan sebelum dilaku- 


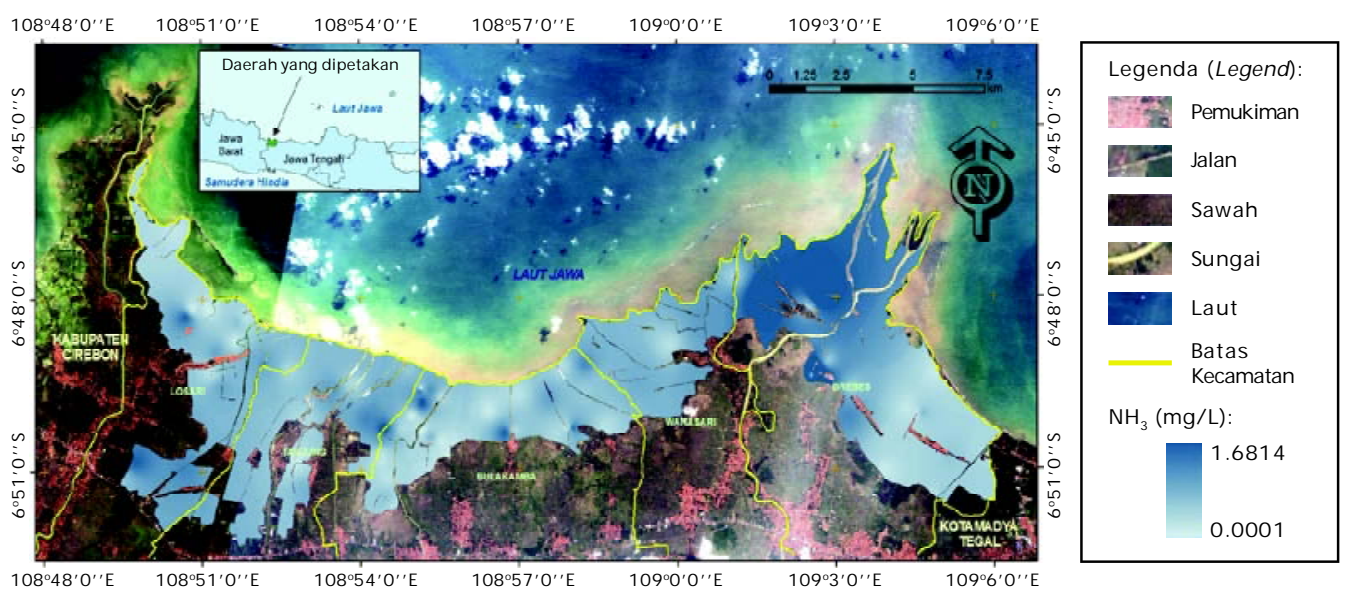

Gambar 9. Peta distribusi spasial amonia $\left(\mathrm{NH}_{3}\right)$ air tambak pertambakan Kabupaten Brebes Provinsi Jawa Tengah

Figure 9. Spatial distribution map of water ammonia $\left(\mathrm{NH}_{3}\right)$ in brackishwater ponds of Brebes Regency Central Java Province

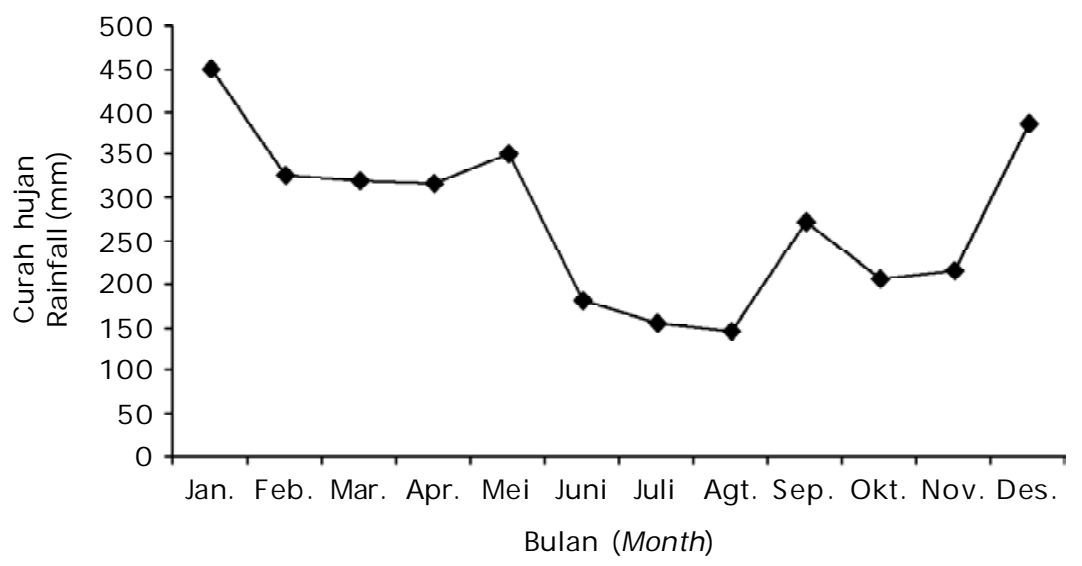

Gambar 10. Grafik curah hujan bulanan di Kabupaten Brebes Provinsi Jawa Tengah tahun 2010

Figure 10. Graph of monthly rainfall in Brebes Regency Central Java Province on 2010

kan penebaran. Pada saat persiapan tambak dilakukan pengeringan tambak dengan tujuan untuk memperbaiki sifat fisik tanah, meningkatkan mineralisasi bahan organik dan menghilangkan bahan-bahan beracun berupa hidrogen sulfida, amonia, dan metan. Oleh karena itu, diperlukan adanya bulan- bulan kering tertentu pada setiap tahun.

\section{Evaluasi Kesesuaian Lahan}

Berdasarkan hasil analisis dengan menggunakan perangkat lunak sistem informasi geografis (SIG) menghasilkan peta kesesuaian lahan tambak. Penentuan kategori kesesuaian diperoleh melalui penjumlahan terhadap nilai dari semua parameter untuk mendapatkan skor akhir sehingga diperoleh nilai kisaran antar kelas. Hasil perhitungan kesesuaian lahan untuk peruntukan kategori kesesuaian ditentukan berdasarkan kisaran atau interval kelas di mana kriteria tingkat kesesuaian dibagi atas empat kelas yaitu: kelas S1: Sangat sesuai (Highly suitable), kelas S2: Cukup sesuai (Moderately suitable), kelas S3: 


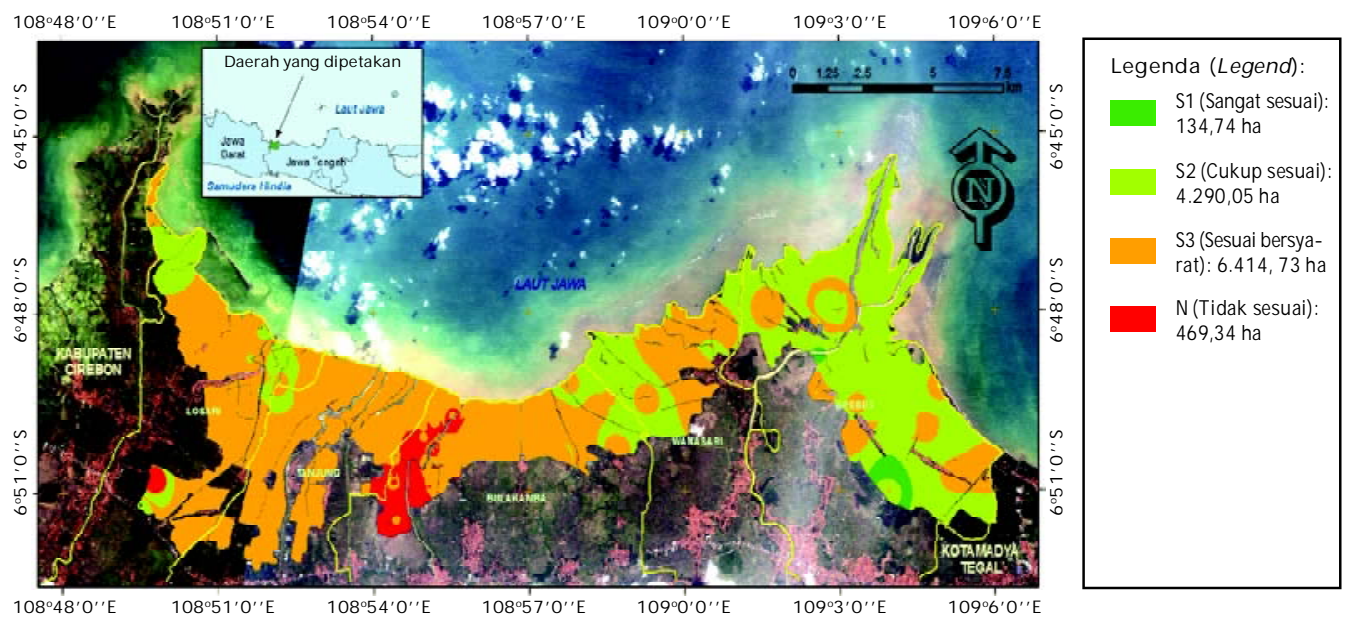

Gambar 11. Peta kesesuaian lahan aktual untuk budidaya udang windu di tambak Kabupaten Brebes Provinsi Jawa Tengah

Figure 11. Actual land suitability map for tiger prawn in brackishwater ponds of Brebes Regency Central Java Province

Sesuai bersyarat (Marginally suitable), dan kelas N: Tidak sesuai (Not suitable). Evaluasi kelas kesesuaian didasari pada petunjuk DKP (2002) yaitu S1 (85\% 100\%), S2 (75\% 84\%), S3 $(65 \% 74 \%)$ dan $\mathrm{N}(<65 \%$.

Hasil evaluasi kesesuaian lahan yang dilakukan di dalam penelitian ini merupakan kesesuaian aktual atau kesesuaian lahan pada saat ini, di mana kelas kesesuaian lahan yang dihasilkan hanya didasarkan pada data yang tersedia, belum mempertimbangkan aspek sosial, ekonomi, finansial, dan aspek lainnya.

Dari hasil analisis kesesuaian Iahan tambak di Kabupaten Brebes, didapat nilai kesesuaian untuk budidaya udang windu, sangat sesuai (S1) seluas 134,70 ha; cukup sesuai (S2) seluas 4.290,05 ha; sesuai bersyarat (S3) seluas $6.414,73$ ha; dan tidak sesuai (N) seluas 469,34 ha (Gambar 11). Daerah yang tergolong sang at sesuai dapat dilakukan budidaya udang dengan teknologi semi- intensif dan intensif, daerah yang tergolong cukup sesuai dapat dilakukan budidaya udang dengan teknologi tradisional dan tradisional plus maupun budidaya ikan bandeng, sedangkan yang tergolong kurang sesuai dapat dilakukan polikultur ikan bandeng dan rumput laut.

\section{KESIMPULAN DAN SARAN}

Hasil analisis kesesuaian Iahan tambak di Kabupaten Brebes, didapat nilai kesesuaian untuk budidaya udang windu, sangat sesuai (S1) seluas 134,70 ha; cukup sesuai (S2) seluas 4.290,05 ha; sesuai bersyarat (S3) seluas $6.414,73$ ha; dan tidak sesuai (N) seluas 469,34 ha.

Perlu diadakan kajian lebih mendalam mewakili setiap musim, untuk mendapatkan hasil yang menggambarkan keadaan tambak sepanjang tahun. Penelitian selanjutnya disarankan mengambil data sosial-ekonomi masyarakat pesisir khususnya yang bekerja pada areal pertambakan agar informasi yang diperoleh mengenai penggunaan Iahan tambak di daerah tersebut akan saling melengkapi hasil penelitian ini.

\section{DAFTAR ACUAN}

Agus, F., Yusrial, \& Sutono. 2006. Penetapan tekstur tanah. Dalam Kurnia, U., Agus, F., Adimihardja, A., \&Dariah, A. (Eds.) Sifat Fisik Tanah dan Metode Analisisnya. Balai Besar Penelitian dan Pengembangan Sumberdaya Lahan Pertanian. Bogor, hlm. 43- 62.

Ahern, C.R. \& McElnea, A.E. 2004. Calculated sulfur parameters. In Acid sulfate soils laboratory methods guidelines. Queensland Department of Natural Resources, Mines, and Energy, Indooroopilly, Queensland. Australia, p. B11-1-B11-2.

Anonim. 2011. Data potensi kelautan dan perikanan Kabupaten Brebes tahun 2010. 
Dinas Kelautan dan Perikanan Kabupaten Brebes. Brebes.

American Public Health Association (APHA). 2005. Standard methods for examination of water and wastewater. APHA- AWWA- WEF, Washington, D.C. 1,185 pp.

Bojo ' rquez-Tapia, L.A., D1 ' az- Mondrago' n, S., \&Ezcurra, E. 2001. GIS based approach for participatory decision making and land suitability assessment. International J ournal of Geographical Information Science, 15(2): 129- 151.

Boyd, C.E. 1995. Bottom soil, sediment, and pond aquaculture. Chapman and Hall. New York, $348 \mathrm{pp}$.

Chanratchakool, P., Turnbull, J.F., Funge- Smith, S., \& Limsuwan, C. 1995. Health management in shrimp ponds. (Second edition). Aquatic Animal Health Research Institute, Department of Fisheries, Kasetsart University Campus. Bangkok, 111 pp.

Departemen Kelautan dan Perikanan. 2002. Modul sosialisasi dan orientasi penataan ruang, laut, pesisir, dan pulau- pulau kecil. Ditjen Pesisir dan Pulau-pulau Kecil. Direktorat Tata Ruang Laut, Pesisir, dan Pulau- Pulau Kecil. Jakarta.

Dinas Hidro- Oseanografi. 2012. Daftar Pasang Surut Tahun 2012. Dinas Hidro- oseanografi TNI AL. Jakarta, $686 \mathrm{hlm}$.

Food and Agriculture Organization (FAO). 1976. A framework for land evaluation. In FAO Soil Bulletin 32. Soil Resources Management and Conservation Service and Water Development Division, FAO. Rome.

Hossain, M.S. \&Das, N.G. 2010. GIS- based multicriteria evaluation to land suitability modelling for giant prawn (Macrobrachium rosenbergii) farming in Companigonj Upazila of Noakhali, Bangladesh. Computers and Electronics in Agriculture, 70(1): 172- 186.

Irianti, D. 2004. Evaluasi kesesuaian lahan pesisir untuk pengembangan budidaya tambak di Kabupaten Purworejo. Tesis. Universitas Diponegoro, Semarang.

Mangunsukardjo, K. 1997. Inventarisasi dan evaluasi sumberdaya lahan. Bahan Pelatihan Sistem Informasi Geografis. Fakultas Geografi Universitas Gadjah Mada. Yogyakarta.

Menon, R.G. 1973. Soil and water analysis: a laboratory manual for the analysis of soil and water. Proyek Survey O.K.T. Sumatera Selatan. Palembang, 190 pp.
Mustafa, A., Rachmansyah, \& Hanafi, A. 2007. Kelayakan lahan untuk budidaya perikanan pesisir. Dalam Susilo, D.S.I., Wiadnyana, N.N., Wijayanti, E., Basmal, J., Asnawi, Supangat, A., Hanggono, A., \&Insan, I. (Eds.) Prosiding Simposium Nasional Hasil Riset Kelautan dan Perikanan Tahun 2007. Badan Riset Perikanan Budidaya. Jakarta, hlm. 141157.

Mustafa, A., Hasnawi, Paena, M., \& Rachmansyah. 2008. Evaluasi kesesuaian Iahan untuk budidaya tambak di Kabupaten Pinrang Provinsi Sulawesi Selatan. J. Ris. Akuakultur, 3(2): 241- 261.

Mustafa, A. \& Rachmansyah. 2008. Kebijakan dalam pemanfaatan tanah sulfat masam untuk budidaya tambak. Dalam Sudradjat, A., Rusastra, I W., \& Budiharsono, S. (Eds.) Analisis Kebijakan Pembangunan Perikanan Budidaya. Pusat Riset Perikanan Budidaya. Jakarta, hlm. 1- 11.

Mustafa, A., Radiarta, I N., \& Rachmansyah. 2011. Profil dan kesesuaian lahan akuakultur mendukung minapolitan. Diedit Sudradjat, A. Pusat Penelitian dan Pengembangan Perikanan Budidaya. Jakarta, $91 \mathrm{hlm}$.

Parsons, T.R., Maita, Y., \& Lalli, C.M. 1989. A manual of chemical and biological methods for seawater analysis. Pergamon Press Oxford, $173 \mathrm{pp}$.

Poernomo, A. 1988. Pembuatan Tambak Udang di Indonesia. Departemen Pertanian. Badan Penelitian dan Pengembangan Pertanian. Balai Penelitian Perikanan Budidaya Pantai. Maros, $40 \mathrm{hlm}$.

Prahasta, E. 2001. Konsep- Konsep Dasar Sistem Informasi Geografi. Informatika. Bandung, $334 \mathrm{hlm}$.

Puntedewo, A. 2003. Sistem informasi geografis untuk pengelolaan sumberdaya alam. Centre for International Forestry Research. Jakarta.

Rachmansyah, Mustafa, A., \& Paena, M. 2010. Karakteristik, kesesuaian, dan pengelolaan lahan tambak di Kota Pekalongan Provinsi Jawa Tengah. J. Ris. Akuakultur, 5(3): 505521.

Rodriguez- Gallego, L., Achkar, M., \& Conde, D. 2012. Land suitability assessment in the catchment area of four Southwestern Atlantic Coastal Lagoons: Multicriteria and optimization modeling. Environmental Management, 50: 140- 152.

Sulaeman, Suparto, \& Eviati. 2005. Petunjuk teknis analisis kimia tanah, tanaman, air, 
Kesesuaian lahan untuk budidaya udang windu di tambak ..... (Rezki Antoni Suhaimi)

dan pupuk. Diedit Prasetyo, B.H., Santoso, D., \& Widowati, L.R. Balai Penelitian Tanah. Bogor, $136 \mathrm{hlm}$.

Tarunamulia, Mustafa, A., dan Tahe, S. 2003. Penentuan letak lapisan pirit $\left(\mathrm{FeS}_{2}\right)$ berkonsentrasi tinggi berdasarkan datum referensi lokal pada tambak yang berasosiasi dengan tanah sulfat masam (studi kasus pada tambak percobaan Maranak, Sulawesi Selatan). J. Pen. Perik. Indonesia, 9(2): 77- 88. 